\title{
Krim Pemutih Wajah dan Keamanannya
}

\author{
Retno Haryanti \\ Program Magister Farmasi, Fakultas Farmasi, Universitas Padjadjaran, Sumedang, 45363 \\ email: retno17005@mail.unpad.ac.id
}

\section{Abstrak :}

Penampilan yang menarik tentu menjadi dambaan setiap orang. Terutama bagi kaum wanita, memiliki wajah yang putih bersih masih menjadi ikon kecantikan sehingga terus dilakukan segala cara untuk mendapatkannya. Salah satu upaya yang dipilih adalah dengan menggunakan produk kosmetika, seperti krim pemutih kulit. Dalam artikel ini dibahas terkait kestabilan krim, bahan berbahaya pada kosmetika, dan cara memilih krim pemutih wajah yang aman.

Keyword : krim, pemutih wajah, kosmetika

\section{Pendahuluan}

Menurut definisi BPOM, kosmetika adalah bahan atau sediaan yang dimaksudkan untuk digunakan pada bagian luar tubuh manusia (epidermis, rambut, kuku, bibir, dan organ genital bagian luar), atau gigi dan membran mukosa mulut, terutama untuk membersihkan, mewangikan, mengubah penampilan, dan/atau memperbaiki bau badan atau melindungi atau memelihara tubuh pada kondisi baik.

Definisi yang senada, tercantum dalam pedoman Food and Drug Administration USA, yaitu bahan yang dimaksudkan untuk diterapkan pada tubuh manusia untuk membersihkan, mempercantik, mempromosikan daya tarik, atau mengubah penampilan tanpa mempengaruhi struktur atau fungsi tubuh. Definisi luas ini juga mencakup bahan yang dimaksudkan untuk digunakan sebagai komponen produk kosmetik. FDA secara khusus mengecualikan sabun dari kategori ini. Biasanya komponen kosmetik merupakan campuran senyawa kimia, beberapa berasal dari sumber alami maupun sintetis.

Pengertian lain, yaitu zat yang dimaksudkan untuk diterapkan pada tubuh manusia untuk pembersihan, mempercantik, meningkatkan daya tarik, atau mengubah penampilan tanpa mempengaruhi struktur atau fungsi tubuh.

Termasuk dalam definisi ini adalah krim kulit, lotion, parfum, lipstik, cat kuku, preparat makeup mata dan wajah, warna rambut, pasta gigi, dan deodoran, serta bahan yang ditujukan untuk digunakan sebagai komponen produk kosmetik. (Pusat Administrasi Pangan dan Obat-obatan AS untuk Food Safety \& Applied Nutrition Office Lembar Fakta Kosmetik, 1995).

Dalam hal ini mencakup pula kosmetik dekoratif seperti lipstick, mascara, eye shadow, foundation, rouge, pembersih kulit, lotion kulit, shampoo, produk hairstyling (gel dan hairspray), parfum dan cologne. 


\section{Sejarah penggunaan kosmetika}

Sejarah penggunaan kosmetik membentang panjang dari sejak era Mesir kuno yang digunakan untuk perlindungan kulit dari sengatan matahari, sesuai sistem kelas / kasta, ataupun rasa keindahan. Salah satu bentuk sediaan kosmetik yang banyak digunakan adalah produk perawatan kulit. Kini, penggunaan kosmetik hadir di hampir setiap belahan bumi dan fakta diketahui bahwa sekitar $15 \%$ dari populasi dunia berinvestasi pada produk pencerah kulit.

Pasar global untuk kosmetik pencerah kulit diprediksi mencapai US \$ 23 miliar pada 2020. Asia saat ini merupakan pasar terbesar; khususnya, India, Jepang, China dan Korea. Menurut laporan biochem SIRONA, Asia menghabiskan sekitar \$13 miliar dalam beberapa tahun terakhir.

\section{Krim pencerah kulit}

Produk kosmetika pencerah/pemutih kulit ini pada umumnya dibuat dalam bentuk krim. Pemilihan bentuk krim ini memiliki tujuan untuk memudahkan pemakainnya yaitu aplikasi pada kulit. Menurut Farmakope Indonesia IV, krim adalah bentuk sediaan setengah padat,mengandung satu atau lebih bahan obat terlarut atau terdispersi dalam bahan dasar yang sesuai.

Istilah ini secara tradisional telah digunakan untuk sediaan setengah padat yang mempunyai konsistensi relatif cair diformulasikan sebagai emulsi air dalam minyak $(\mathrm{A} / \mathrm{M})$ atau minyak dalam air (M/A). Krim terdiri dari emulsi minyak dalam air atau dispersi mikro kristal asam-asam lemak atau alkohol berantai panjang dalam air, yang dapat dicuci dengan air dan lebih ditujukan untuk pemakaian kosmetika dan estetika.

Ada dua tipe krim yaitu, krim tipe minyak air $(\mathrm{m} / \mathrm{a})$ dan krim tipe air minyak $(\mathrm{a} / \mathrm{m})$. pemilihan zat pengemulsi harus disesuaikan dengan jenis dan sifat krim yang dikehendaki. Krim tipe $A / M$ digunakan sabun polivalen, span, adeps lanae, koleterol, dan cera sedangkan untuk krim tipe M/A digunakan sabun monovalen seperti trietanolamin, natrium laurisulfat, kuning telur, gelatinum, caseinum, $\mathrm{CMC}$, dan emulgidum.

\section{Kestabilan krim}

Pengenceran krim hanya dapat dilakukan jika diketahui pengencernya yang cocok dan dilakukan dengan teknik aseptik. Krim yang sudah diencerkan harus digunakan dalam jangka waktu 1 bulan. Pilihan pengawet pada krim umumnya digunakan metilparaben (nipagin) dengan kadar $0,12 \%$ hingga $0,18 \%$ atau propilparaben (nipasol) dengan kadar $0,02 \%$ hingga $0,05 \%$.

Kestabilan krim akan terganggu atau rusak jika sistem campurannya terganggu, terutama disebabkan oleh perubahan suhu dan perubahan komposisi yang disebabkan perubahan salah satu fase secara berlebihan atau zat pengemulsinya tidak tercampurkan satu sama lain. Penyimpanan krim dilakukan dalam wadah tertutup baik atau tube ditempat sejuk.

Krim pemutih kulit yang beredar di pasaran biasanya merupakan campuran beberapa komponen bahan. Tujuannya agar memberikan efek sebagaimana yang diinginkan. Namun sayangnya, tidak semua produk krim pemutih kulit aman digunakan.

Akibatnya bukan kulit wajah yang putih bersih yang diperoleh namun gangguan kulit maupun penyakit berbahaya seperti kanker, yang justru didapatkan. Penyebabnya adalah adanya penambahan bahan berbahaya dalam krim pemutih wajah itu. 


\section{Bahan berbahaya pada kosmetika}

Sebagaimana dilansir dalam Public Warning BPOM No. B-IN.05.03.1.43.12.17.5965 tanggal 11 Desember 2017 tentang Kosmetika yang mengandung Bahan Berbahaya, selama tahun 2017 Badan POM RI menemukan 26 jenis kosmetika mengandung bahan berbahaya. Temuan tersebut didominasi oleh produk kosmetika dekoratif dan produk perawatan kulit dengan jenis bahan berbahaya yang teridentifikasi digunakan di dalamnya antara lain merkuri, bahan pewarna merah K3 dan merah K10. Ketiga bahan tersebut dapat berefek buruk bagi kesehatan.

Merkuri bersifat karsinogenik (menyebabkan kanker) dan teratogenik (mengakibatkan cacat pada janin), bahan pewarna merah K3 dan merah K10 juga bersifat karsinogenik. Selain itu, ditemukan pula kosmetika mengandung BKO yang seharusnya tidak diperbolehkan terkandung dalam kosmetika, yaitu Klindamisin.

Anorganik merkuri seperti merkuri klorida, merkuri oxida, amoniated merkuri, merkuriklorida) adalah bentuk-bentuk merkuri yang sering terdapat dalam produk pemutih kulit. Ini adalah zat yang sangat toksik dimana mekanisme kerjanya adalah dengan menghambat produksi melanin dengan berkompetisi terhadap tembaga dalam tyrosinase. Akibatnya kulit terlihat lebih bersih.

Absorpsi per kutan melalui epidermis, kelenjar keringat, kelenjar sebasea ataupun folikel rambut. Penyerapan kulit secara signifikan dipengaruhi oleh beberapa faktor seperti hidrasi pada stratum korneum dan frekuensi penggunaan pada kulit. Eliminasi utamanya melaui sekresi urin.

Pada pemakaian yang terus menerus, efek kumulatif dari paparan dosis rendah yang sangat lama dapat memicu efek nefrotoksik, proteinuria dan radang ginjal. Pada kondisi tersebut, sistem susunan saraf pusat juga akan dapat dipengaruhi oleh inorganik Hg. Faktanya, bahkan walaupun penetrasi merkuri sangat buruk karena ada sawar darah-otak tapi paparan yang lama dan terus-menerus akan dapat menghasilkan akumulasi pada sistem saraf pusat dan mengakibatkan neurotoksisitas.

Selain merkuri, bahan lain yang sering ditambahkan ke dalam kosmetika adalah hidrokuinon. Hidroquinone dengan metabolit utama benzene yang juga banyak digunakan dalam produk pemutih kulit. Zat ini sangat dikenal bersifat hepatotoksik dan agen karsinogenik. Saat kontak dengan kulit, hidroquinone beraksi sebagai substrat alternate bagi tyrosin. Penggantian tyrosine ini, dimana yang seharusnya berubah menjadi melanin, hidroquinon bermetabolisme menjadi quinon dan radikal bebas. Radikal bebas inilah yang akan menyerang membran melanosit yang menyebabkan terjadinya efek sitotoksik .

\section{Cara Memilih Krim Pemutih Wajah yang Aman}

Oleh karena itulah, sangat penting bagi kita untuk memastikan terlebih dahulu keamanan produk krim pemutih wajah yang akan kita gunakan. Lalu, bagaimanakah cara kita untuk mengetahui suatu produk aman atau tidak?

1. Periksa kondisi kemasan kosmetik masih dalam keadaan baik atau tidak. Periksa secara teliti kemasan produk tersebut. Masih bagus ataukah sudah ada kerusakan seperti misalnya segel terbuka, ada kebocoran, dll.

2. Periksa juga saat akan digunakan apakah tercium bau tengik ataupun konsistensi krim telah berubah. Bisa jadi krim tersebut telah mengalami kerusakan. Jangan pula menggunakan kosmetika yang sudah rusak atau mengalami perubahan baik warna maupun bentuknya

3. Baca dengan seksama informasi yang tertera pada etiket dan label.

4. Periksa tanggal kadaluarsa produk. Jangan pernah membeli produk yang telah kadaluarsa.

5. Gunakan kosmetik yang bermutu, aman dan bermanfaat serta memenuhi persyaratan penandaan. Setiap konsumen/pengguna kosmetika sebaiknya perlu periksa tanda daftar kosmetik tersebut yang ditunjukkan dari nomor notifikasi BPOM. Penomeran Notifikasi kosmetik akan mencantumkan kode dua huruf dan 11 digit angka, dimana: 
- 2 huruf awal = kode benua,

o Kode benua :

o NA = produk Asia (termasuk produk lokal).

o NB = Produk Australia

o NC = produk Eropa.

o ND = Produk Afrika

o NE = produk Amerika.

- 11 angka terdiri dari : 2 angka pertama kode negara, 2 angka berikutnya tahun notifikasi, 2 angka untuk jenis produk dan 5 angka terakhir adalah nomor urut notifikasi.

Jika tidak terdaftar BPOM maka lebih baik jangan digunakan.

6. Gunakan kosmetika sesuai petunjuk pada label .

7. Perhatikan pula kegunaan maupun cara penggunaan krim tersebut, pastikan sesuai dengan kebutuhan kita maupun kondisi kulit kita.

8. Lakukan tes kepekaan kulit. Sebelum menggunakan kosmetik terlebih dahulu lakukan tes kepekaan kulit dengan cara menggunakan kosmetika pada daerah di belakang telinga atau di balik telapak tangan untuk menghindari efek yang tidak diinginkan, terutama untuk produk yang baru pertama kali digunakan. Apabila kita telah mengetahui bahwa kulit kita alergi terhadap suatu bahan sedangkan bahan tersebut ada di dalam komposisi krim itu maka jangan digunakan.

9. Tidak mudah mempercayai berbagai penawaran produk kosmetika. Kita juga perlu mencari kebenaran kegunaan produk kosmetika yang ditawarkan

10. Perhatikan apakah penandaan produk kosmetika sudah lengkap dan sesuai dengan yang dipersyaratkan, contoh : nama dan alamat perusahaan, kegunaan dan cara penggunaan, komposisi, tanggal produksi atau tanggal kadaluarsa, dll.

11. Hati-hati terhadap produk palsu atau produk tiruan.

12. Hindari penggunaan kosmetika milik orang lain, yang belum tentu sesuai dengan kondisi kulit kita.

13. Simpan kosmetik dengan baik, dalam menyimpan kosmetik sebaiknya hindari tempat penyimpanan yang dapat terpapar sinar matahari, dan lebih baik kosmetika disimpan pada tempat dengan suhu kamar (25oC) atau mengikuti aturan penyimpanan yang tertera pada produk.

14. Segera hentikan pemakaian kosmetik bila terjadi reaksi yang tidak diinginkan dan hubungi dokter bila terjadi efek samping kosmetika, seperti munculnya perasaan terbakar, ruam, gatal atau kemerahan pada kulit. Bila konsumen/pemakai mengalami efek samping, maka dapat menghubungi dokter dan melaporkan ke perusahaan yang memproduksi atau importir produk atau ke Badan POM.

Selain itu, masyarakat kini semakin mudah untuk dapat mengakses segala informasi yang terkait kosmetika melalui beberapa website berikut ini :

1. Cek status produk kosmetika yang beredar di wilayah Indonesia melalui Badan POM dengan menghubungi bagian ULPK Badan POM, dan Balai POM setempat atau dapat diakses melalui website www.pom.go.id sebelum kosmetika digunakan.

2. Peraturan Persyaratan Teknis Bahan Kosmetika dapat diakses melalui www.notifkos.pom.go.id

3. Aplikasi public warning BPOM

4. Cek ijin edar produk melaui Cek klik BPOM dengan alamat www.ceknie.pom.go.id

Jadi, sudah amankah produk krim pemutih wajah yang Anda?

\section{Daftar Pustaka}

Al-Saleh, I., Doush, E., Shinwari, N., al Baradei, Khogali, R., \& al-amodi. (2005). does low mercury containing skin-lightening cream(fair \& lovely) affect the kidney, liver and brain of female mice? Cutan Ocul.Toxicol., 24, 11-29.

Anief, M, (2002), Ilmu Meracik Obat, Gadjah Mada University Press, Yogyakarta. 53.

Anonim, (1995), Farmakope Indonesia, Edisi IV, Departemen Kesehatan RI, Jakarta. 12. http://www.sironabiochem.com/products/skinlightening/.

Ansel H.C,1989,Pengantar Bentuk Sediaan Farmasi, edisi IV, Penerbit Universitas Indonesia

Bocca, B., Pino, A., Alimonti, A., \& Forte, G. (2014). Toxic metals contained in cosmetics: A status report. Regulatory Toxicology and Pharmacology, 68(3), 447-467. https://doi.org/10.1016/j.yrtph.2014.02.008 
Chan, T. Y. K. (2011). Inorganic mercury poisoning associated with skin-lightening cosmetic products. Clinical Toxicology, 49(10), 886-891. https://doi.org/10.3109/15563650.2011.626425

"Cosmetics and Your Health - FAQs". Womenshealth.gov. November 2004. Archived from the original on 2013-03-12.

Engler. (2005). Mercury “bleaching"creams. J.Am.Acad.Dermatol, 52, 1113-1114.

Enguita, \& Leitao, A. . (2013). Hydroquinone : environmental pollution, toxicity and microbial answers. Biomed.Res.Int., 542168.

Gillbro, \& Olsson, M. . (2011). The melanogenesis and mechanism of skin lightening agents existing and new approaches. Int.J.Cosmet.Sci, 33, 210-221.

Lewis, Carol (2000). "Clearing up Cosmetic Confusion."FDA Consumer Magazine

Olumide, Akinkugbe, A. ., Altraide, D., Mohammed, T., Ahamefule, N., Ayanlowo, S.,Essen, N. (2008). Complication of chronic use of skin lightening cosmetics. Int.J.Dermatol., 47, 344-353.

Schneider, Günther et al (2005). "Skin Cosmetics" in Ullmann's Encyclopedia of Industrial Chemistry, Wiley-VCH, Weinheim. doi:10.1002/14356007.a24_219 